\title{
Lenin and Nietzsche in the Althusserian Perspective: Philosophy as Eternal Battle
}

\author{
ALEKSANDR SAUTKIN, ELENA PHILIPPOVA \\ Department of Philosophy, Social Sciences and Social Security Law, Murmansk Arctic State University, 15 Kapitana Egorova Street, \\ Murmansk, 183038, Russia \\ Email: sautkin72@mail.ru; fatalJ@list.ru
}

\begin{abstract}
The article is devoted to the identification of some intersection points in the philosophical ideas of F. Nietzsche and V. Lenin. The analysis of Lenin's views, given by Louis Althusser in a number of his works, can serve as the methodological basis for such a comparison. In this perspective, Lenin's understanding of philosophy is characterized by the fact that philosophy is treated not only as a theory but, above all, as a practice of struggle for domination. Lenin and Nietzsche share the dynamic view of the universe, the idea of the leading role of contradictions and struggle in the world's being. Philosophy appears as an expression of some hidden impulses, which are ultimately reducible to the will to power. Therefore, for both thinkers knowledge appears not as the result of pure and objective cognition, but as a product of the struggle of power instincts, and knowledge itself is a necessary element of any power order.
\end{abstract}

Keywords: dialectics, materialism, idealism, practice, will to power, politics

\section{INTRODUCTION}

The diverse and ambiguous influence of Nietzsche's thought on Russian culture has long been the theme of special research, and the first thing that attracts interest is the reception of Nietzschean ideas during the Soviet era. While the pre-revolutionary Russian philosophers' and artists' interest in Nietzsche is quite obvious and can be easily explained from the general cultural context of the fin de siècle period, its comparable influence on the Bolshevik political and cultural elite requires some special analysis.

First and foremost, it is necessary to mention here the work of G. L. Kline (1969), as well as the works of Bernice Rosenthal, whose editorial board published the books 'Nietzsche in Russia' (1986) and 'Nietzsche and Soviet Culture: Ally And Adversary' (1994). The result of those studies was a fundamental monograph 'New Myth, New World: from Nietzsche to Stalinism' (Rosenthal 2002). The role of Nietzsche in the Russian literature of the so-called 'Silver Age' was studied by E. Clowes (1988), certain aspects were examined in the works of M. Deppermann (1998/99), H. Günther (1993), M. A. Gillespie (1996), Yu. V. Sineokaya (2008).

One of those 'non-obvious' aspects of the 'Nietzsche in Russia' theme is the influence of the German thinker's ideas on Vladimir Lenin, while the interest in Nietzsche of other 
Russian Marxists, including those close to Bolshevism, was clearly recognized in pre-revolutionary times (for example, Berdyaev wrote about Lunacharsky that he 'mixed a sauce from Marx, Avenarius and Nietzsche' (Berdiaev 1994: 11)).

For the official Soviet philosophical discourse, such a comparison would look absolutely absurd. However, this comparison did not seem strange, for example, to such a perceptive right thinker as Pierre Drieu la Rochelle, who in his work 'Fascist Socialism' asked the following question: 'Nietzsche formed Mussolini, we know it. But did he not influence Lenin?' And then he answered his own question: Nietzsche's philosophy - a philosophy of action and coming-to-be - imposed an imprint on Lenin, definitely influenced his temperament, despite the fact that, apparently, 'Lenin did not read a single line of the anti-socialist philosopher' (Drieu la Rochelle 2001: 86).

In fact, Drieu La Rochelle was wrong, believing that the leader of the Bolshevik revolution was unfamiliar with Nietzsche's works. As shown by Aldo Venturelli, there was a German edition of 'The Birth of Tragedy' in Lenin's personal library, a copy of 'Thus Spoke Zarathustra' was kept in Lenin's Kremlin office, and during his stay abroad before the revolution Lenin had the opportunity to read Nietzsche in French translations in the libraries of Geneva and Paris (see Venturelli 1993: 320-330).

There is every reason to suppose that Nietzsche's ideas were somehow included in the topics discussed by Lenin and his friend writer Maxim Gorky, who was heavily influenced by Nietzsche's philosophy (see Clowes 1988). Rethinking of the Nietzschean individualism and 'immoralism', coordinating his inspirations with revolutionary Marxist teaching takes place in the so-called doctrine of 'God-building'. Lenin took those ideas extremely critically (see Lenin 1973: 123). Accordingly, systematic criticism of God-building assumed some familiarity with its ideological foundations, including Nietzscheanism.

In the published works of Lenin there are practically no references to Nietzsche's texts. As an exception can serve two fragments from the 'Philosophical Notebooks', in one of which Nietzsche is mentioned in connection with individualism, while in the other he is critically regarded as one of the forerunners of the pragmatic concept of truth (Rosenthal 2002: 130-131).

Thus, there is evidence of Lenin's acquaintance with Nietzsche's works, and his silence about the ideas of the 'philosophizing with a hammer' thinker creates a special hermeneutic situation: it is enough to imagine Lenin as a Nietzschean (in the order of a mental experiment) to reveal their similarity in those Lenin's statements that are not directly related to Nietzsche. In the present study, we made an attempt of presenting not so much the catalog of Nietzschean motifs found in Lenin's worldview, but some meta-philosophical position that allows us to explain the match between Lenin and Nietzsche certain ideas, caused by their similar understanding of philosophy. The approach of Althusser helps to clarify the essence of the Leninist view of philosophy. We are interested in the consideration of the very essence of philosophy that the French neo-Marxist finds with Lenin, thus setting an intriguing approach to the activity of philosophers as a special kind of practice - the practice of struggle and will-domination. In our opinion, that understanding of philosophy is also quite in tune with the spirit of our time (in particular, if we bear in mind the post-colonial critical discourse, feminist and post-feminist studies, etc.)

\section{LENIN THROUGH ALTHUSSER'S LENSES: THE NON-PHILOSOPHICAL THEORY OF PHILOSOPHY}

To paraphrase Engels (1975: 274), we can quite say that 'the great basic question of all philosophy, especially of more recent philosophy', is the question of what is philosophy. Here we have 
no intention of pointing out the importance of self-determination of philosophy as a special type of knowledge, we are talking about the external status of philosophy as a social phenomenon, and, consequently, we also need an external point of view on philosophy.

In his 'Lenin and Philosophy' report, read in the French Philosophical Society on 24 February 1968, Althusser points out the importance of gaining this external position and declares: 'I believe that what we owe to Lenin, something which is perhaps not completely unprecedented, but certainly invaluable, is the beginnings of the ability to talk a kind of discourse which anticipates what will one day perhaps be a non-philosophical theory of philosophy [italics supplied - Authors]' (Althusser 1971b: 27).

What view can be external to philosophy? We suggest that it is the Politic's point of view. Philosophy, no matter how much it disowns its involvement in politics, nevertheless is inextricably linked with politics. This connection is not the involvement of some philosophical doctrines into the struggle of political forces; it is rather an expression of the political essence of philosophy itself, usually denied by 'philosophical laborers' (Nietzsche's expression). Therefore we can fully explain both the disdain of Lenin's ideas on the part of university professors and Lenin's masterly curses in their address (Lenin 1977: 340).

So, philosophy is associated with class interests, and, consequently, with the political expression of the contradiction between these interests, that is, with the class struggle. It seems that drawn by Althusser parallels with Freud are not accidental: politics is 'the repressed' of philosophy (der verdrängten Inhalt der Philosophie), politics is a kind of neurotic point of philosophy, and Lenin acts as a figure akin to a psychoanalyst, who brings out the true content of the unconscious into the realm of consciousness - and makes us recognize this connection between philosophy and politics as irremovable (see Althusser 1971b: 33).

Althusser speaks about 'absolutely unlimited insistence', with which Lenin neglects all philosophical details, abolishing the complexity and variety of philosophical positions and doctrines, reducing the centuries-old history of philosophy to the constant struggle of the two camps, two tendencies.

Lenin wrote that

'One expression of the genius of Marx and Engels was that they despised pedantic playing with new words, erudite terms, and subtle "isms", and said simply and plainly: there are a materialist line and an idealist line in philosophy, and between them, there are various shades of agnosticism (Lenin 1977: 147).

The result of this reduction is the denial that philosophy has history, because if the whole content of philosophy is a struggle of materialism and idealism in their different variations, then it is necessary to consider this content as the 'eternal return', and not as history in the proper sense (as a set of unique intellectual events connected with a continuous line of progressive development).

That is why Althusser declares that 'philosophy has no history, philosophy is that strange theoretical site where nothing really happens, nothing but this repetition of nothing' (1971b: 55). Nevertheless, philosophy is still a 'theoretical construction', although a 'strange' one, and moreover, it is inextricably linked with science, although unlike science it does not have its own object. After all, we do not consider the 'matter/spirit' opposition to being the object of philosophy - the opposition fundamental for Lenin, but, according to Althusser, subjected to the 'infinite and purposeless' inversion by emphasizing one or another of its members.

At this point in our consideration, the previously proposed political nature of philosophy is revealed at last: since it does not have its own object (in the sense as the object of science), 
it may have something different. The latter may be the orientation of philosophy to the struggle for dominance of one of the two hierarchies of concepts, and these hierarchies are determined by a possible inversion in the 'matter/spirit' opposition. In other words, philosophy, in the Althusserian interpretation of Lenin's ideas, appears not only as a special kind of theory, but also as a practice, and this is the practice of struggle for domination, for power. In the 'Lenin before Hegel' report, made a year after the presentation of the 'Lenin and Philosophy' report, Althusser briefly (and more categorically) repeats the main points of his previous declaration. Among his assertions, we find the following: 'Philosophy is a practice of political intervention carried out in a theoretical form' (Althusser 1971c: 107).

\section{NITZSCHEANISM-LENINISM: PHILOSOPHY AS KAMPFPLATZ}

The dominant position of philosophy in the struggle for the fusion of theory with the political practice of the workers' movement means that philosophy is on the front line of attack and must always be ready to accept the blow of alien-class philosophical schools. The very space of knowledge becomes the sphere of power distribution: knowledge and power are united and support each other, as it was stated by Michel Foucault a few years later in his 'Discipline and Punish' (see Foucault 1995: 27). Any operations in the space of knowledge mean nothing else than a shift of the front line in a fierce struggle for power, and those shifts are caused precisely by the political actions of the opposing sides.

Althusser, with references to 'Materialism and Empirio-Criticism', asserts that 'philosophical practice' for Lenin is an intervention in the field of theory, expressed, firstly, in the formulation of the complete categories, and secondly, in the specific function of these categories. This function consists of "drawing a dividing-line" inside the theoretical domain between ideas declared to be true and ideas declared to be false, between the scientific and the ideological' (Althusser 1971b: 61).

Actually, any philosophy is the desire to carry out this 'dividing-line', protecting itself and its science from the influence of opposing philosophical and scientific discourses, pushing them from the sphere of theory to its borders with the goal of finally getting rid of hostile concepts. That is why philosophy does not have its own subject and its own history. Philosophy as a political tool has a 'void' character, and its meaning is determined only by the movement of the 'dividing-line,' which itself is emptiness. In this eternal battle of philosophical trends (for Lenin, of the two fundamental ones - materialism and idealism) only scenery changes, but the essence remains unchanged, therefore, the history of philosophy appears as Kampfplatz - the battlefield.

Lenin reveals the dynamic picture of the being of thought: he perceives philosophy as a zone of conflict, as a space of permanent struggle, and this struggle is a struggle for power. This understanding is contained in Lenin's statement that philosophy has a party character:

Recent philosophy is as partisan as was philosophy two thousand years ago. The contending parties are essentially - although this is concealed by a pseudo-erudite quackery of new terms or by a weak-minded non-partisanship - materialism and idealism. The latter is merely a subtle, refined form of fideism, which stands fully armed, commands vast organisations and steadily continues to exercise influence on the masses, turning the slightest vacillation in philosophical thought to its own advantage (Lenin 1977: 358).

Here may be seen the intersection of Lenin's thought with the ideas of Nietzsche. 'Philosophy is partisan' means that on the field of philosophy we always observe the clash of the individual, private positions ('perspectives', as Nietzsche would say), and behind every philosophical position there is something that philosophers may not admit - the will to power. Lenin believes that 
declaring one's own non-partisanship in philosophy means hiding (consciously or unconsciously) one's true motives and aspirations substanced by power (Lenin 1977: 341). While criticizing his opponents, Lenin first of all points to their blindness with respect to the political character of their own philosophical theses, which seem for them to be excluded from the struggle for power.

The perception of philosophy as a space of struggle and manifestation of the will to overcome paradoxically unites such different figures as Lenin and Nietzsche. Of course, we do not assert the identity of their views, but a number of common points are evident.

Thus, both of them inherent in the idea of the dynamic character of the world - be it the world of thought, nature or society. In this case, we can digress from the fact that Nietzsche's dynamic is inscribed in the model of the 'eternal return of the same' and is rooted in the vital-biological origin of the will to power, which acquires a cosmic character and permeates the whole universe, while Lenin's view presupposes a linear vision of history and exclusively political interpretation of the will to power in terms of the 'class struggle'.

Anyway, both thinkers perceive the world through the prism of contradiction and struggle. Perhaps this conflictological character of Lenin's worldview determined his intense interest in Hegelian dialectics, so clearly manifested in the 'Philosophical Notebooks'. Dialectics for Lenin is at the same time a method of cognition of reality and an expression of the essential nature of reality - contradictory, restless, eternally abiding struggle with itself (see, for example, the well-known section of the 'Philosophical Notebooks', entitled 'On the Question of Dialectics' (Lenin 1976: 357-358)).

In our opinion, Hegelian theses in Lenin's works acquire a completely different meaning being placed in the context of Nietzschean thought, according to which it is necessary to regard 'all phenomena, movement, Becoming ... as the establishment of relations of degree and of force, as a contest' (Nietzsche 1914b: 61).

Arguing in 'Twilight of Idols' about philosophical reason's negation of the importance of sensual experience, Nietzsche writes with a 'respectful' reference to Heraclitus: "Reason" makes us falsify the testimony of the senses. The senses are not lying when they show becoming, passing away, and change... But Heraclitus will always be right in thinking that being is an empty fiction. The "apparent" world is the only world: the "true world" is just a lie added on to it...' (Nietzsche 2005: 167-168).

This dynamism of the worldview and consideration of the struggle as the eternal law of the single, but at the same time internally pluralistic world for both philosophers entail the idea that the desire for power is the main impulse for most practical aspirations, and in the sphere of knowledge - even for all of them without exception, and the separation of theory from practice in their analysis is supposed to be something unacceptable.

We have already mentioned the 'partisan' nature of Lenin's philosophy, so let us only note that in the confrontation between theoretical knowledge systems Nietzsche also saw the struggle of hidden practical impulses (or, as he would say, 'affects' or 'instincts'). He wrote in 'The Will to Power' (fr. 432): 'This is a pernicious distinction, as if there were an instinct of knowledge, which, without inquiring into the utility or harmfulness of a thing, blindly charged at the truth; and then that, apart from this instinct, there were the whole world of practical interests' (Nietzsche 1914a: 338-339).

The author of 'The Will to Power' saw his own task in showing what instincts are active behind all these pure theorists $\langle\ldots\rangle$ The struggle between systems $\langle\ldots\rangle$ is one which involves very special instincts (forms of vitality, of decline, of classes, of races, etc.). The so-called thirst for knowledge may be traced to the lust of appropriation and of conquest... (Nietzsche 1914a: 339). 
Nietzsche writes about 'instinct', and Lenin about 'class interest', but abstracting from the content of these concepts, we can quite easily grasp the typological similarity of the German philosopher's and Russian politician's worldviews, which is reflected in their texts: Nietzsche sees the hidden suppression of instincts in the European philosophers' thought, beginning with Socrates and Plato, while Lenin puts a similar task, although a lesser one - to reveal concessions to idealism and fideism in the works of Russian Marxists and therefore to show their reactionary (or even counterrevolutionary) character. In either case, we see an attempt to find the hidden motive, the driving force that determines the work of philosophical thought, and in both cases, the force is recognized as the desire to overcome the enemy, to surpass him, to impose him with one's own 'perspective' of the worldview.

Analysing a series of passages from 'Zarathustra', dedicated to the will to power, Walter Kaufmann indicates that for Nietzsche 'the will to truth is a function of the will to power' (Kaufmann 1974: 203), evidence of which is found, for example, in 'Beyond Good and Evil', where Nietzsche explicitly states: 'Philosophy is this tyrannical drive itself, the most spiritual will to power, to the "creation of the world", to the causa prima' (Nietzsche 2002: 11).

Meeting in the same field of perception of thought as a struggle, Lenin and Nietzsche nevertheless disagree on the general understanding of the nature of this struggle: unlike Nietzsche, Lenin regards it exclusively in socio-political terms. 'Class struggle' becomes a universal image of the conflict universe of thought, according to Lenin. He sees a philosopher as a figure of power, a representative of knowledge power, which ensures the preservation of the boundaries of class interests.

\section{ABSOLUTE METHOD: DIALECTICS IN THE SERVICE OF THE REVOLUTION}

What can we say on the inner content of philosophy if it has neither its own object nor history? It turns out that we can only consider the ways by which the production of the same 'dividing-line' in the sphere of thought is carried out. In other words, we are talking only about the method, and all and any philosophy is reducible to the question of the method, according to Althusser. He wrote: 'Lenin takes from Hegel the following proposition: there is only one thing in the world which is absolute, and that is the method or the concept of the process, itself absolute' (Althusser 1971c: 123). This Absolute Method and simultaneously Absolute Process is nothing but dialectics, i.e. 'the concept of a process without a subject, as it is to be found in Capital, and elsewhere, too, in Freud, for example' (Althusser 1971c: 124).

Any 'morality' interpreted as a 'perspective' always has its hidden purpose, it always hides something from its subject. From the point of view of Nietzsche, one cannot speak of a subject as something that has become, and even more so, of a real one: 'No subject-"atoms". The sphere of a subject increasing or diminishing unremittingly, the center of the system continually displacing itself $<\ldots .>$ Not a "substance", but rather something which in itself strives after greater strength; and which wishes to 'preserve' itself only indirectly (it wishes to surpass itself)' (Nietzsche 1914b: 17). That 'something which in itself strives after greater strength' is nothing but the will to power, while the subject arises as its surface effect, without stability and certainty. At the same time, Nietzsche's world appears united, and the subject arises precisely because the will to power is realized: these are not two different worlds, but one.

Movement as a non-subject process is another point of the meta-philosophical construction that unites Nietzsche and Lenin. In the light of what has been said, we get a complete explanation of Lenin's keen interest in Hegelian dialectics, as well as Lenin's identification of philosophy with materialistic dialectics cleansed of Hegel's idealism, being for 
Lenin the only reliable tool of political struggle in the field of theory. Philosophy is no longer thought of as an instrument external to politics, used as necessary in the political struggle - now it is the very instrument of politics, having a political essence, being politics itself. As we understand, this is no longer the involvement of intellectuals into class battles on either side, but their constant participation in the production of the power regimes by means of philosophical discourse.

If we recall Althusser's idea of the 'ideological apparatuses of the State', which are nothing else than outwardly neutral institutions of civil society (Althusser 1971a: 153), then one can find the real reason of Lenin's enmity for 'university philosophy' The fall of Nietzsche out of the context of philological and philosophical academic activity and his contempt for 'philosophical laborers' again demonstrate his paradoxical closeness to Lenin's attitudes toward philosophy. 'I am going to insist', Nietzsche wrote, 'that people finally stop mistaking philosophical laborers and scientific men in general for philosophers'. What distinguishes them? Their task does - for the task of the true philosopher is to create values (Nietzsche 2002: $105-106){ }^{1}$

The closeness of Nietzsche's and Lenin's arguments about 'philosophers' is revealed even in the similar manner of expression, in their very style - sarcastically harsh, invective, sometimes reaching deliberate rudeness.

As a Marxist, Althusser takes Lenin's lessons in the perspective of purifying science of false ideological influences and scientific support of the class struggle, for philosophy is a 'representative of politics' in the field of theory (while facing science) and a 'representative of science' in politics (facing struggling classes). However, a broader interpretation of the Lenin-Althusser lesson is also possible: in the possibility of criticism of the very mechanisms linking all knowledge with power in its many manifestations.

\section{CONCLUSIONS}

We can conclude that Lenin, being familiar with the ideas of Nietzsche, did not directly appeal to them, but it is still possible to reveal a certain similarity between the meta-philosophical attitudes of the two thinkers.

Lenin's appeal to the consideration of philosophical problems was not due to his philosophical interest. The approach of Althusser helps to clarify the essence of the Leninist view of philosophy. He considered Lenin's merit the creation of a non-philosophical theory of philosophy. In the Althusserian interpretation of Lenin's ideas, philosophy is a special kind of theory, inextricably linked with science but having no its own object or history. Philosophy is also a practice - the practice of struggle for domination, for power. Philosophy is integrated into social relationships and is designed to perform certain functions, has political nature and is associated with class interests and class struggle. Philosophy is a political tool for drawing the 'dividing-line'.

We can note a number of intersections of Lenin's thought with the ideas of Nietzsche: a) the world is perceived through the prism of dynamics, contradiction, and struggle, while movement is seen as a non-subject process; b) in the confrontation between theoretical

1 Thomas Lambert writes that 'Nietzsche views value creation as a social rather than metaphysical phenomenon. $\langle\ldots\rangle$ his ideal of the genuine philosopher is of an individual whose influence extends beyond the academy to shape society to conform to his will' (Lambert 2018: 16). In the same article, we find a meaningful criticism of the constructivist approach to value creation, presented by Alex Silk (see Silk 2015). 
knowledge systems there is a struggle of hidden practical impulses or motives; c) the desire for power is considered to be the main impulse for most practical aspirations; knowledge and power being united and supporting each other.

Thus, the intersection of the thought strategies of Lenin and Nietzsche allows us to understand the essence of philosophy as a special life practice connected with the Politics. The political function of an intellectual is determined by his objective location within the mechanism of power-generating, from which he has no way out, and therefore the intellectual must first realize that he is not freely floating between social worlds, but is an element in the machine of power and the one who is able to change the operation mode of this machine.

Received 9 November 2018

Accepted 20 May 2019

\section{References}

1. Althusser, L. 1971a. 'Ideology and Ideological State Apparatuses', in Lenin and Philosophy and Other Essays, ed. L. Althusser. Translated from the French by B. Brewster. New York, London: Monthly Review Press, 127-186.

2. Althusser, L. 1971b. 'Lenin and Philosophy', in Lenin and Philosophy and Other Essays, ed. L. Althusser. Translated from the French by B. Brewster. New York, London: Monthly Review Press, 23-70.

3. Althusser, L. 1971c. 'Lenin Before Hegel', in Lenin and Philosophy and Other Essays, ed. L. Althusser. Translated from the French by B. Brewster. New York, London: Monthly Review Press, 107-126.

4. Berdiaev, N. 1994. 'Philosophical Verity and Intelligentsia Truth', in Vekhi. Landmarks. A Collection of Articles about Russian Intelligentsia, translated and edited by M. S. Shatz and J. E. Zimmerman. Armonk, New York: M. E. Sharp, Inc., 1-16.

5. Clowes, E. 1988. The Revolution of Moral Consciousness: Nietzsche in Russian Literature, 1890-1914. Dekalb: Northern Illinois University Press.

6. Davies, R. D. 1976. 'Nietzsche in Russia, 1892-1917. A Preliminary Bibliography', Germano-Slavica 2: $107-146$.

7. Deppermann, M. 1998/99. 'Nietzsche in der Sowjetunion. "Den begrabenen Nietzsche ausgrabe", Nietzsche-Studien. Internationales Jahrbuch für die Nietzsche-Forschung 27: 480-514.

8. Drieu La Rochelle, P. 2001. Fashistskiy sotsializm (Fascist Socialism). Translated into Russian by A. Shestakov. Saint Petersburg: Vladimir Dal'.

9. Ducange, J.-N.; Wolikow, S. 2017. 'Le siècle du léninisme', Actuel Marx 62(2): 11-25.

10. Engels, F. 1975. 'Ludwig Feuerbach und der Ausgang der klassischen deutschen Philosophie', in Karl Marx, Friedrich Engels. Werke. Band 21. Berlin: (Karl) Dietz Verlag, 259-307.

11. Foucault, M. 1995. Discipline and Punish. The Birth of the Prison. Translated by A. Sheridan. New York: Vintage Books.

12. Gillespie, M. A. 1996. Nihilism Before Nietzsche. Chicago: The University of Chicago Press.

13. Günther, H. 1993. Der sozialistische Übermensch. M. Gor'kij und der sowjetische Heldenmythos. Stuttgart, Weimar: Verlag J. B. Metzler.

14. Kaufmann, W. 1974. Nietzsche: Philosopher, Psychologist, Antichrist. Princeton: Princeton University Press.

15. Kline, G. L. 1969. “Nietzschean Marxism” in Russia', in Demythologizing Marxism: A Series of Studies on Marxism, ed. F. J. Adelmann. Chestnut Hill, Mass.: Boston College, 166-183.

16. Lambert, T. 2018. 'Nietzsche on Creating and Discovering Values', Inquiry 62(1): 49-69.

17. Lenin, V. I. 1977. 'Materialism and Empirio-Criticism', in V. I. Lenin. Collected Works. Vol. 14, translated by A. Fineberg, ed. C. Dutt. Moscow: Progress Publishers.

18. Lenin, V. I. 1976. 'Philosophical Notebooks', in V. I. Lenin. Collected Works. Vol. 38, translated by C. Dutt, ed. S. Smith. Moscow: Progress Publishers.

19. Lenin, V. I. 1973. 'Letter to Maxim Gorky', in V. I. Lenin. Collected Works. Vol. 35, translated by A. Rothstein, ed. R. Daglish. Moscow: Progress Publishers, 121-124.

20. Lewis, W. S. 2005. Louis Althusser and the Traditions of French Marxism. Lanham: Lexington Books. 
21. Nietzsche, F. 2005. 'Twilight of the Idols', in Friedrich Nietzsche. The Anti-Christ, Ecce Homo, Twilight of the Idols, and Other Writings, translated by J. Norman, eds. A. Ridley and J. Norman. Cambridge: Cambridge University Press, 153-230.

22. Nietzsche, F. 2002. Beyond Good and Evil. Translated by J. Norman, eds. R.-P. Horstmann and J. Norman. Cambridge: Cambridge University Press.

23. Nietzsche, F. 1914a. The Will to Power. Vol. I (Books I and II), translated by A. M. Ludovici, ed. O. Levy. Edinburg, London: T. N. Foulis.

24. Nietzsche, F. 1914b. The Will to Power. Vol. II (Books III and IV), translated by A. M. Ludovici, ed. O. Levy. Edinburg, London: T. N. Foulis.

25. Rosenthal, B. G. 2002. New Myth, New World: from Nietzsche to Stalinism. University Park, PA: The Pennsylvania State University Press.

26. Rosenthal, B. G. (ed.). 1994. Nietzsche and Soviet Culture: Ally and Adversary. Cambridge: Cambridge University Press.

27. Rosenthal, B. G. (ed.). 1986. Nietzsche in Russia. Princeton: Princeton University Press.

28. Silk, A. 2015. 'Nietzschean Constructivism: Ethics and Metaethics for All and None', Inquiry 58(3): 244-280.

29. Sineokaya, Y. V. 2008. Tri obraza Nietzsche v russkoy kulture (Three Images of Nietzsche in Russian Culture). Moscow: Institute of Philosophy, Russian Academy of Sciences.

30. Venturelli, A. 1993. 'Eine historische Peripetie von Nietzsches Denken: Lenin als Nietzsche-Leser?', Nietzsche-Studien. Internationales Jahrbuch für die Nietzsche-Forschung 22: 320-330.

ALEKSANDR SAUTKIN, ELENA PHILIPPOVA

\title{
V. Leninas ir F. Nietzsche L. Althusserio vertinimu: amžinojo mūšio filosofija
}

\begin{abstract}
Santrauka
Siekiama nustatyti kai kuriuos F. Nietzsche's ir V. Lenino filosofinių idejjų sankirtos taškus. L. Althusseris daugelyje savo darbų yra pateikęs V. Lenino pažiūrų analizę, jo filosofiją traktuoja ne tik kaip teoriją, bet, visų pirma, kaip kovos praktiką siekiant valdžios. V. Leninui ir F. Nietzsche'i būdingas bendras dinamiškas požiūris ị visatą, prieštaravimų ir kovos pasaulyje lemiamo vaidmens idejja. Filosofija pasirodo kaip tam tikrų paslèptų impulsų, kurie galiausiai yra redukuotini ị galios valią, išraiška. Todèl abiem mąstytojams pažinimas atrodo ne kaip gryno ir objektyvaus supratimo rezultatas, bet kaip galios instinktų kovos išdava, o pats žinojimas yra būtina bet kokios tvarkos dalis.
\end{abstract}

Raktažodžiai: dialektika, materializmas, idealizmas, praktika, galios valia, politika 